\begin{abstract}
論 文
分散制御によるロボットマスゲーム*

東 俊一 ${ }^{\dagger} \cdot$ 泉 晋作 $^{\dagger} \cdot$ 杉江 俊治 ${ }^{\dagger}$

\section{Halftone Mass Games by Fixed Number of Mobile Robots*}

Shun-ichi AzUmA ${ }^{\dagger}$, Shinsaku IzUmI ${ }^{\dagger}$ and Toshiharu SUGIE $^{\dagger}$

This paper presents a distributed control method of multi-robot systems for performing the mass games, i.e., to display a given image as a formation of a number of mobile robots. The proposed method is based on the combination of a coverage control method and halftone image processing. The performance is demonstrated by numerical simulations with several standard images.

\section{1.はじめに}

複数のロボットによる協調作業においては, 個々のロ ボットが互いの情報を交換しながら自律的に動作し，グ ループ全体の目的達成が求められる．このとき，各口 ボットは , 他のすべてのロボットの情報を得られるわけ ではなく，近傍のロボットの情報だけが得られるような 状況か想定される .このような, ロボット群の分散制御 は，交通システム，警備・防災システム，宇宙システム など, 幅広い応用が期待されており，近年盛んに研究が なされている $[1,2]$.

兴の一方で, 先行研究では, おもに, 曲線の組合せで 構成されるような，幾何学的に単純な図形を表現する フォーメーション形成が考えられていた（たとえば，文 献 [3-7]）．したがって，つぎのステップとして，より複 雑なものをロボット群のフォーメーションとして実現で きるようになれば, 弚の応用範囲をさらに広げられるも のと考えられる .

乥こで, 本論文では, ロボット群にマスゲームを実現 させるような分散制御問題を考える.ここでいうマス ゲームとは, Fig.1のように，ロボット群を高台から眺 めたときに，任意に与えられた濃淡画像に見えるような フォーメーションを形成することを意味している．この ようなマスゲームを実現するためには，与えられた画像

* 原稿受付 2011 年 9 月 12 日

$\dagger$ 京都大学 大学院 情報学研究科 Graduate School of Informatics, Kyoto University; Gokasho, Uji, Kyoto 6110011, JAPAN

Key Words: multi-agent system, mobile robot, distributed control, halftone image processing.

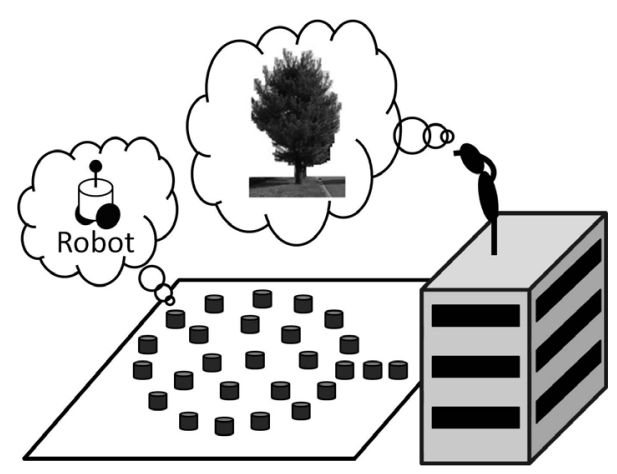

Fig. 1 Mass games by mobile robots

の濃淡情報までもフォーメーションとして表現しなくて はならないため, これまでに得られている手法に比べて， より高度な分散制御技術が必要とされる。

本論文では, この目的のために，分散型被覆制御 [6] とハーフトーン画像処理 [8] を組み合わせた制御器を提 案する . 前者は, ある空間内にロボットを均一に配置す る分散制御法であり，後者は，与えられた濃淡画像を見 た目を保存したまま 2 值化する画像処理法であるが，こ れら一見違った手法を適切に組み合わせることで，マス ゲームのための分散制御器が得られる. 提案法の有効性 は, いくつかの標準画像に対する数值実験を通して検証 される。

本章の最後に，つぎの点を強調しておく．まず，ロボッ 卜群の分散制御の研究において, マスゲームの実現を目 的としたものは, 著者らの知る限り，これまでに考えら れてはおらず，本論文が初めての取り組みとなる．また， 提案制御法は, 制御工学と画像処理という異なる分野で 
得られた手法を融合させたものであるが, 従来研究にお いては, 兴のような画像処理の手法を導入したものは見 当たらない．この点においても，本論文の成果は，従来 のものとは大きく異なっている .

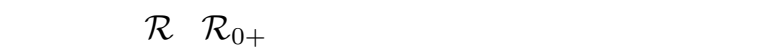

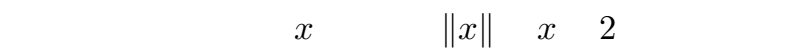
が, 別の種類のノルムを用いる場合は $\|x\|_{p}$ のように記す． 集合Iの幕集合を $\mathcal{P}(\mathcal{I})$ で表す .たとえば，P $(\{1,2,3\})=$ $\{\emptyset,\{1\},\{2\},\{3\},\{1,2\},\{1,3\},\{2,3\},\{1,2,3\}\}$ であり，幕 集合は，集合の集合という点に注意する．つぎに， $\mathcal{R}^{2}$ 内の有界な凸集合 $\mathcal{Q}$ を考える。QQ に含まれる異なった 座標を持つ点 $i=1,2, \ldots, n$ に対し，弚の座標の集合を $\mathcal{X}:=\left\{x_{1}, x_{2}, \ldots, x_{n}\right\}$ と記す .このとき，集合 $\mathcal{V}_{i}(\mathcal{X}):=$ $\left\{q \in \mathcal{Q} \mid\left\|q-x_{i}\right\| \leq\left\|q-x_{j}\right\|\right.$ for all $j$ s.t. $\left.j \neq i\right\}$ を, $\mathcal{X} に$ おける点 $i$ のボロノイ領域とよぶ . また,$\{1,2, \ldots, n\}$ を頂 点集合とし, $\left\{(i, j) \in\{1,2, \ldots, n\}^{2} \mid \mathcal{V}_{i}(\mathcal{X}) \cap \mathcal{V}_{j}(\mathcal{X}) \neq \emptyset\right\}$

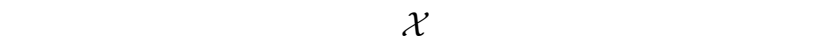
$G(\mathcal{X})$ で表す．頂点 $i$ に対し, $\mathcal{V}_{i}(\mathcal{X}) \cap \mathcal{V}_{j}(\mathcal{X}) \neq \emptyset$ を満た す頂点 $j(G(\mathcal{X})$ において頂点 $i$ と隣接する頂点 $)$ を， $i$ の近傍とよぶ: .

\section{2. 問題設定}

\section{1 対象システム}

Fig. 2 に示される二次元空間上の群ロボットシステム を考える．これは， $n$ 個の移動ロボットで構成され，各 ロボットのダイナミクスはつぎのように与えられる .

$$
\dot{x}_{i}(t)=u_{i}(t) \quad(i=1,2, \ldots, n)
$$

ここで, $x_{i}(t) \in \mathcal{R}^{2}, u_{i}(t) \in \mathcal{R}^{2}$ はロボット $i$ の位置およ び入力である .

時刻 $t$ におけるすべてのロボットの位置をまとめて， 集合 $\mathcal{X}(t):=\left\{x_{1}(t), x_{2}(t), \ldots, x_{n}(t)\right\}$ で記し，(時刻 $t$ にお (ナる) フォーメーションとよぶ . ロボットの行動領域が 有界な凸集合 $\mathcal{Q} \subset \mathcal{R}^{2}$ によって定義されたとき，フォー メーション $\mathcal{X}(t)$ におけるロボット $i$ のボロノイ領域は $\mathcal{V}_{i}(\mathcal{X}(t)), \mathcal{X}(t)$ のドロネーグラフは $G(\mathcal{X}(t))$ で表され る.また，初期フォーメーションは $\mathcal{X}(0):=\mathcal{X}_{0} \subset \mathcal{Q}^{n}$ と 与えられる。

つぎに, 上記のシステムに対し，二つの仮定を設ける .

(仮定 1) すべてのロボット共通の座標系が存在し , 各ロボットは产の座標系における自己の位置情報を任意 の時刻 $t$ で取得できる.

(仮定 2) 時刻 $t$ においては,ドロネーグラフ $G(\mathcal{X}(t))$ 上の辺で結ばれたロボット間でのみ，位置情報を交換す ることができる．

前者は, 各ロボットが, GPS 受信機のような, 絶対座 標系での位置情報を得られる装置を持つことを意味する． 後者は，ロボット間の情報交換に関する条件である．

\section{2 マスゲーム問題}

本論文で考える問題について説明する .

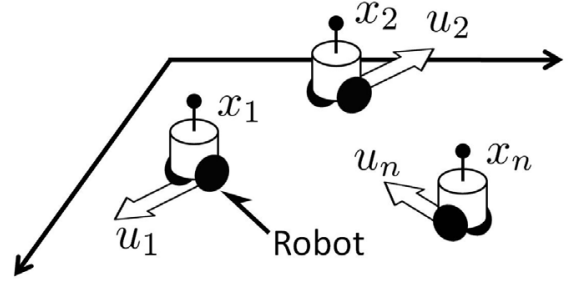

Fig. 2 Multi-robot system to be studied

Fig. 2 のシステムに，あるフォーメーションを分散的 な制御器で実現させることを考える .このとき, 目標 となるフォーメーションは, Fig. 1 に示されるように， Fig. 2 のシステムを高台から見たときに，任意に与えら れた濃淡画像を表現するようなものである . 弚の画像は， $\mathcal{R}^{2}$ 内の有界な凸集合 $\mathcal{Q}$ 上において定義される可積分関 数 $\varphi: \mathcal{Q} \rightarrow[0,1]$ として与えられる . また,$\varphi(q)$ で位置 $q \in \mathcal{Q}$ における画素値を表し,$\varphi(q)=0$ は白色,$\varphi(q)=1$ は黑色, $\varphi(q) \in(0,1)$ は中間色 (灰色) を意味する.

各ロボットには, 分散型のローカル制御器

$$
u_{i}(t)=f\left(x_{1}(t), x_{2}(t), \ldots, x_{n}(t), \mathcal{N}_{i}(t)\right)
$$

が備えられている.ここで, $\mathcal{N}_{i}(t) \subseteq\{1,2, \ldots, n\}$ は，ド ロネーグラフ $G(\mathcal{X}(t))$ における頂点 $i$ (ロボット $i$ ) の近 傍の集合であり，常に $i \in \mathcal{N}_{i}(t)$ が成り立っている.また， $f: \mathcal{R}^{2 n} \times \mathcal{P}(\{1,2, \ldots, n\}) \rightarrow \mathcal{R}^{2}$ は, この制御器を記述す る関数であり, 近傍集合 $\mathcal{N}_{i}(t)$ に属するロボットの位置だ けに依存するようなものと仮定する．たとえば， $\mathcal{N}_{2}(t)=$ $\{2,3, \ldots, n\}$ のとき, $f\left(x_{1}(t), x_{2}(t), \ldots, x_{n}(t), \mathcal{N}_{2}(t)\right)$ の值 は $x_{1}(t)$ に依存しない，すなわち，任意の $\left(x_{11}, x_{12}\right) \in$ $\mathcal{R}^{2} \times \mathcal{R}^{2}$ に対して,$f\left(x_{11}, x_{2}(t), \ldots, x_{n}(t), \mathcal{N}_{2}(t)\right)=$ $f\left(x_{12}, x_{2}(t), \ldots, x_{n}(t), \mathcal{N}_{2}(t)\right)$ が成立する .この意味にお いて，(2) 式は分散制御器となっている.なお, 関数 $f$ はロボットの識別子 $i$ に依存しないことにも注意する .

このとき, 本論文では以下の問題を考える .

【マスゲーム問題】目標画像 $\varphi: \mathcal{Q} \rightarrow[0,1]$ と初期フ オーメーション $\mathcal{X}_{0} \subset \mathcal{Q}^{n}$ が任意に与えらえるものとする . このとき, 最終フォーメーション $\mathcal{X}(\infty)$ が, 画像 $\varphi$ を表 現するような分散制御器 $f: \mathcal{R}^{2 n} \times \mathcal{P}(\{1,2, \ldots, n\}) \rightarrow \mathcal{R}^{2}$ を求めよ .

つぎの点に注意されたい．まず，この問題では，「画像 の見た目」という人間の感性に関することが仕樣になっ ている. 兴れゆえ，弚の仕樣を数学的に表現することは 一般に難しいが，ここでは「目標画像で表現されている 対象物や状況を概ね認識できる」程度のことを想定して いる .この意味は後ほど明らかになる．つぎに，すべて のロボットは, 目標画像 $\varphi$ に関する情報を持つものと 仮定している．したがって，この問題の解は， $\varphi$ を用い て定義される.最後に, 本論文では, 問題の本質部分に 絞った議論を行うため, ロボット間の衝突や, ロボット の入力制約などは考慮しない . 


\section{3. 提案手法}

マスゲーム問題の解を導出する .ここで提案するのは，

(i) Cortésらによって提案された被覆制御器 [6]

(ii) ハーフトーン画像処理（たとえば，文献 $[8,9]$ )

を組み合わせたものである．以下では，(i) を簡単に紹 介したうえで, 問題の解となる分散制御器を与える .

\subsection{Cortésらの被覆制御器 $[6]$}

フォーメーション $\mathcal{X}:=\left\{x_{1}, x_{2}, \ldots, x_{n}\right\}$ に関し，つぎ の評価関数を考える .

$$
J(\mathcal{X}):=\sum_{i=1}^{n} \int_{\mathcal{V}_{i}(\mathcal{X})} h\left(\left\|q-x_{i}\right\|\right) \phi(q) d q
$$

$h: \mathcal{R}_{0+} \rightarrow \mathcal{R}_{0+}$ は, $\mathcal{Q}$ 上で区分的微分可能な単調非減少 関数であり， $\phi: \mathcal{Q} \rightarrow \mathcal{R}_{0+}$ は, $\mathcal{Q}$ 上で可積分な関数であ る.一般に，集合 $\mathcal{S}$ 上のスカラ值関数 $\psi$ の $p$ ノルムが，

$$
\|\psi\|_{p}:=\left(\int_{\mathcal{S}}|\psi(q)|^{p} d q\right)^{\frac{1}{p}}
$$

と定義されることに注意すれば， $\mathcal{S}=\mathcal{V}_{i}(\mathcal{X}), \psi(q)=$ $\left\|q-x_{i}\right\|, h\left(\left\|q-x_{i}\right\|\right)=\left\|q-x_{i}\right\|^{p}, \phi(q) \equiv 1$ の対応関係 のもとで, $(3)$ 式の中の積分は,$q$ を変数とするスカラ值 関数 $\left\|q-x_{i}\right\|$ の $p$ ノルムの $p$ 乗を表している .この際， $\phi(q) \not \equiv 1$ の場合は, 重みが導入されたノルムのようなも の ${ }^{1}$ 表すことになる.したがって, 兴の積分は, ボロノ イ領域 $\mathcal{V}_{i}(\mathcal{X})$ に含まれるすべての点 $q$ とボロノイ点 $x_{i}$ の間の（一般化された）距離に近いもの ${ }^{2}$ となっている . これを, ボロノイ領域の個数分，足し合わせて，集合 $\mathcal{Q}$ 上のすべての点 $q$ を考慮したものが $J(\mathcal{X})$ である .

$J(\mathcal{X})$ を小さくするフォーメーション $\mathcal{X}:=\left\{x_{1}, x_{2}, \ldots, x_{n}\right\}$ は, 関数 $h$ にって定義される゙ ある種の距離的な意味” において , 集合 $\mathcal{Q}$ 上のすべての点 $q$ の近くに $x_{i}$ が存在 するものであり，弚れは被覆とよばれている.この際， $\phi$ は, 集合 $\mathcal{Q}$ 上の各点の重要度を表す重み関数であり， 大杂倠把にいえば，所望の場所に，より多くのロボットを 配置させるものである .

各ロボットが 2.1 のように与えられ, 評価関数 $J(\mathcal{X})$ が $h\left(\left\|q-x_{i}\right\|\right):=\left\|q-x_{i}\right\|^{2}$ によって定義される場合は， ある分散型の制御器が存在し ,

・光れに対する閉ループ系が, $J(\mathcal{X}(t))$ の時間微分を 準負定にすること

- 閉ループ系の最大の不変集合は, $J(\mathcal{X})$ の局所最小 値を与えるフォーメーションの集合に等しいこと が知られている $[6]$. この事実とラサールの不変性原理 より，光のような分散型制御器を用いれば，任意の初期 フォーメーション $\mathcal{X}_{0}$ から,$J(\mathcal{X})$ の局所最小值を与える フォーメーションに遷移できることになる．光のような

${ }^{1} \phi(q) \not \equiv 1$ のとき , ノルムの公理を満たさないので「ノ ルムのようなもの」と表現している .

2距離の公理を満たすものではない.
制御器のひとつは,

$$
u_{i}(t)=-K\left(x_{i}(t)-c\left(\mathcal{V}_{i}(\mathcal{X}(t))\right)\right)
$$

で与えられる．ここで， $K \in \mathcal{R}_{0+} \backslash\{0\}$ は，この制御器 のゲイン ( $K$ はスカラ ) であり, $c\left(\mathcal{V}_{i}(\mathcal{X}(t))\right) \in \mathcal{R}^{2}$ は , ボロノイ領域 $\mathcal{V}_{i}(\mathcal{X}(t))$ の重み付き重心

$$
c\left(\mathcal{V}_{i}(\mathcal{X}(t))\right):=\frac{\int_{\mathcal{V}_{i}(\mathcal{X}(t))} q \phi(q) d q}{\int_{\mathcal{V}_{i}(\mathcal{X}(t))} \phi(q) d q}
$$

である . また , ボロノイ領域 $\mathcal{V}_{i}(\mathcal{X}(t))$ は , ドロネーグラ フ $G(\mathcal{X}(t))$ における頂点 $i$ の近傍の位置 $\left(j \in \mathcal{N}_{i}(t)\right.$ に対 する $\left.x_{j}\right)$ だけに依存するため,$c\left(\mathcal{V}_{i}(\mathcal{X}(t))\right)$ は近傍の口 ボットの位置から計算することができる，すなわち (4) 式は $(2)$ 式の形の分散制御器である.

\section{2 提案制御器}

続いて, マスゲーム問題の解となる制御器を与えよう. まず，前節で述べた通り，(3) 式の $J(\mathcal{X})$ を最小にする ような制御器を用いると, $\phi(q)$ の值が大きい点 $q$ の近く には，比較的多くのロボットが集まることが期待される . すなわち， $\phi$ は , 最終フォーメーションにおけるロボッ 卜の「密度分布」に対応している。

谷の一方で，画像処理の分野では，与えられた濃淡画 像を, 白と黑の画素だけを持つ 2 值画像に , 見た目を保 存したまま変換する「ハーフトーン画像処理」が知られ ている.これは, 広く知られている単純 2 値化処理 ${ }^{3}$ とは 異なり, 黑と白の中間色 (灰色) を, 黑の画素をまばら に配置することで疑似的に表現するものである . 言い換 えれば, 元の画像の持つ濃淡情報を, 黑の画素の「密度 分布」として表現するものである. 兴のような 2 值画像 はハーフトーン画像とよばれ, 弚の一例はFig. 3 のよう に与えられる . 元の画像で濃い灰色になっている部分に は, ハーフトーン画像の対応箇所で, 黑の画素が多く配 置されていることが確認できるであろう .

以上の二つの事実に着目すると，与えられた画像 $\varphi$ の 濃淡情報をロボットの密度分布 $\phi$ に対応させる，すなわ ち, 画像の濃い部分には多数のロボットを配置し, 淡い 部分には少数のロボットを配置するようにすれば, マス ゲーム問題の解になり方うである . この考えに基づき，

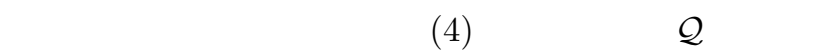
の定義域とし，

$$
\phi(q):=e^{30(\varphi(q)-1)}
$$

としたものを提案する.ここで $\phi$ は, 目標画像 $\varphi$ の関数 であり, 結果として得られる (4) 式の制御器は, 目標画 像 $\varphi$ と近傍のロボットの位置を変数とする関数になる.

\footnotetext{
${ }^{3}$ 各画素の画素值を，あらかじめ定められた閾値と比較 し, 白か黑の画素値に量子化していく方法 .
} 


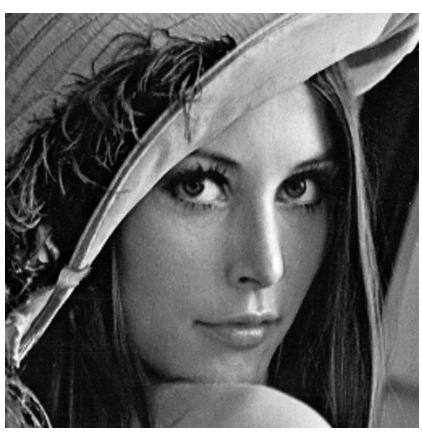

(a) Original image

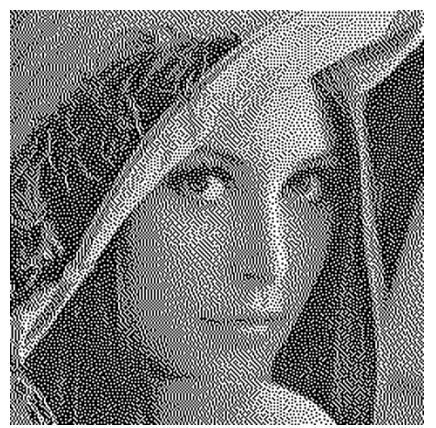

(b) Halftone image

Fig. 3 Halftoning

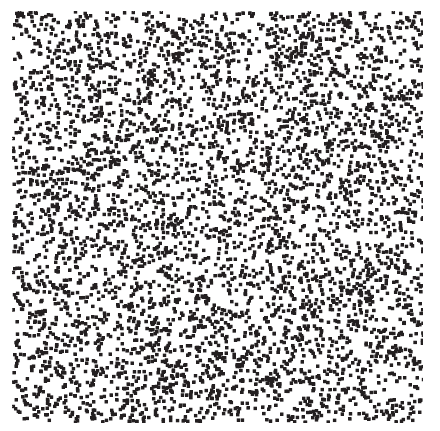

(a) Initial formation

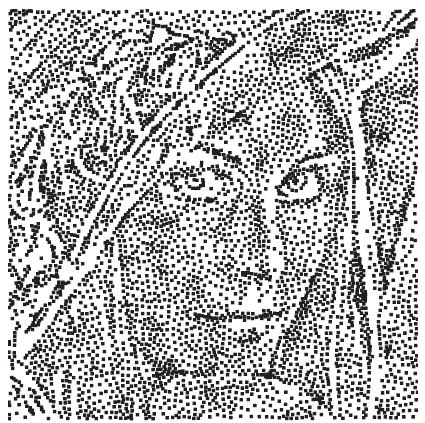

(c) $t=2$

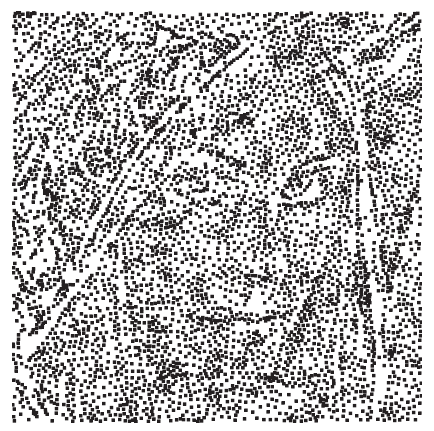

(b) $t=1$

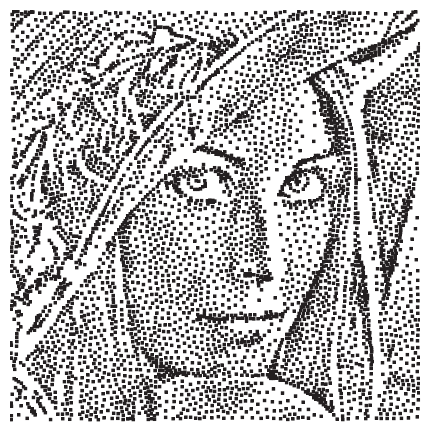

(d) $t=10$

Fig. 4 Lenna

$\phi に$ に $\phi(q):=\varphi(q)$ のように, 画像 $\varphi$ を直接設定す ることも考えられるが，実際には，(5)式のように， $\varphi$ に 単調な非線形変換を行ったものを設定している .これは， 画像を直接設定して数值実験を実施したところ, 結果と して得られるフォーメーションの見た目のコントラスト が, 元の画像 $\varphi$ に比べて弱くなるため，(5) 式のように して，画像の濃淡の差を強調するようにしている．また， (5) 式の $e$ のべきの 30 という值は, さまざまな画像を用 いた数值実験を行い, 最終フォーメーションが人間の見 た目に適合するようなものとして選んでいる.これを選 ぶにあたっての予備実験の結果は付録に示している .

\section{4. 数値実験による検証}

数値実験によって，提案手法を検証する．

Fig. 2 のシステムにおいて , ロボット数を $n:=5000$ と
する . 目標画像 $\varphi$ は, Fig. 3(a)の標準画像 Lenna[10] で ある.これは, 画素数が $256 \times 256$ で, 画素値の階調数 が 256 (8ビット) のディジタル濃淡画像である . この とき, $\mathcal{Q}:=[0,256]^{2}, \varphi(q) \in\{0,1 / 255,2 / 255, \ldots, 1\}$ とな る.また , 各ロボットの初期位置は, $\mathcal{Q}$ 上の一樣分布に 従って確率的に選んだ .

$K:=2$ として, (4) 式と (5) 式の提案制御器を用いた ときの結果が , Fig. 4である . (a)の初期フォーメーショ ンからの時間発展が (b)-(d) で示されているが, 時間の 経過に伴い，徐々に目標画像に近づいていくことが確認 できる．とくに，十分な時間が経過した後のフォーメー

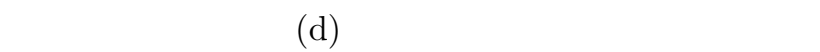
て，与えられた目標画像の濃淡までも表現されている点 が観察できる . 


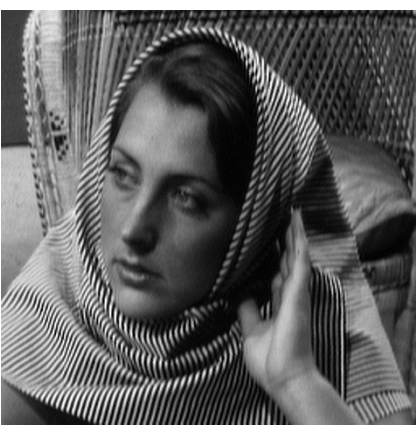

(a) Original image

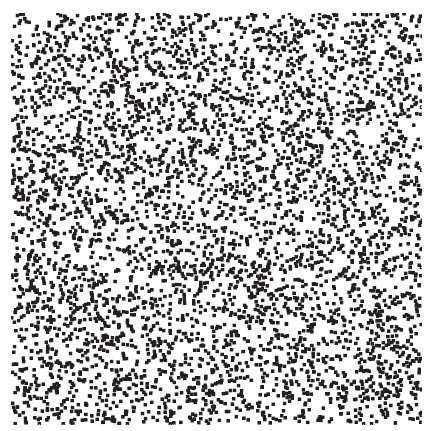

(b) Initial formation

Fig. 5 Barbara

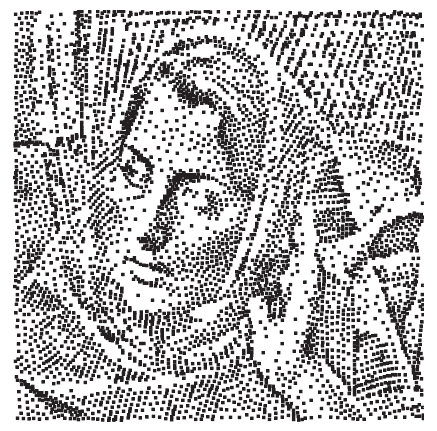

(c) Final formation

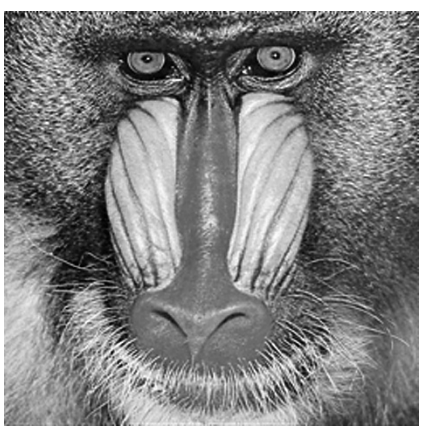

(a) Original image

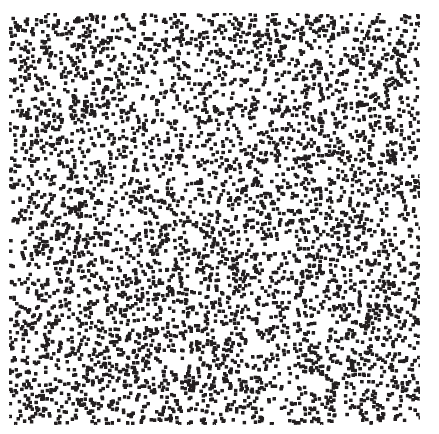

(b) Initial formation

Fig. 6 Mandrill

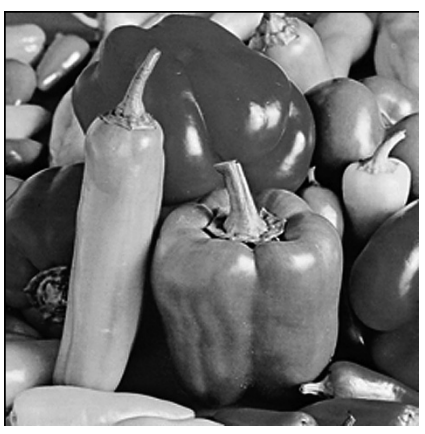

(a) Original image

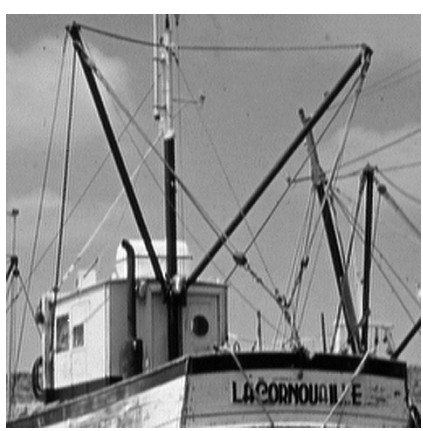

(a) Original image

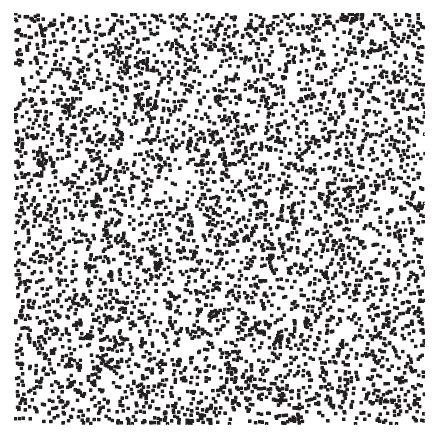

(b) Initial formation

Fig. 7 Pepper

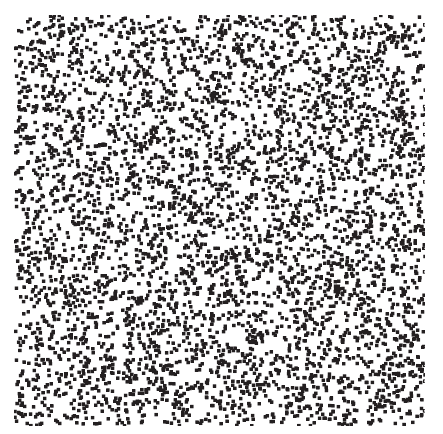

(b) Initial formation

Fig. 8 Boat

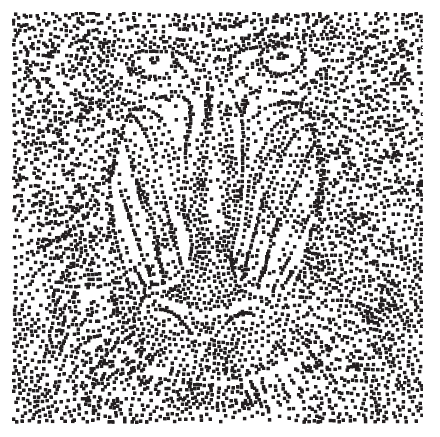

(c) Final formation

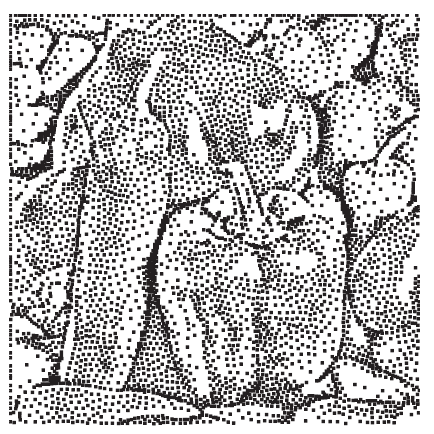

(c) Final formation

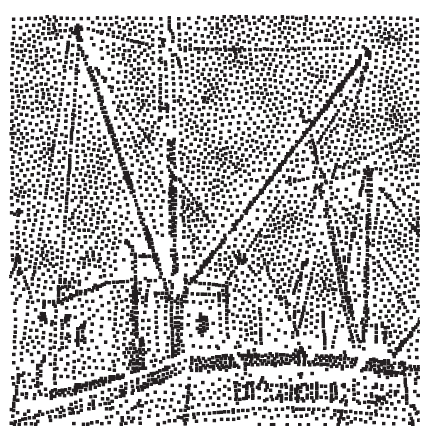

(c) Final formation 
同樣の検証を，別の 4 種類の標準画像に対して行った 結果が, Fig. 5 から Fig. 8である. 光れ光れ, 目標画像， 初期フォーメーション,$t=10$ の (ほぼ最終の) フォー メーションを示している.いずれの場合も，良好な結果 が得られており, 提案制御器がさまざまな種類の画像に 対して適用できることがわかる.

(注意 1) (4) 式の制御器は, $J(\mathcal{X})$ の局所的な最小化 を実現するものであるため，すべての初期フォーメー ションに対して, 目標画像の表現を理論的に保証するも のではない．しかし，画像処理分野でベンチマークとし て用いられている標準画像集 SIDBA (Standard Image Data-BAse) [10] に収録されている 12 枚すべての画像 に対し, 上記と同樣に確率的に発生させた 10 種類の初期 フォーメーションを用いて数值実験を行ったところ(計 120 種類の初期フォーメーション) , マスゲームの実現が 失敗することは一度もなかった . すなわち，初期フォー メーションに片寄りのない場合には , 提案法によってほ ぼ確実にマスゲームを実現できるものと考えられる .方，初期フォーメーションに片寄りのある場合 ( $\mathcal{Q}$ 内で ロボット群が片寄って配置された場合) には, 提案制御 器による最終フォーメーションが目標画像 $\varphi(q)$ を表現で きないことがある．この場合，ある一定期間，各ロボッ トにランダムウォークをさせて初期フォーメーションの 片寄りを解消し，弚こを新たな初期状態として提案制御 器を適用すればよい。

(注意 2) 本論文では, ロボットの数が固定された条 件のもとでのマスゲーム問題を考察している．したがっ て , 提案法は , すべてのロボットが集合 $\mathcal{Q}$ 内に存在しな くてはならない場合の解法として有効である一方，黑画 素の数が固定されてしまうため，与えられた画像の明暗 が , フォーメーションによって形成される画像の明暗に 一致しない . 今後, 本論文の問題設定とは別のものとし て，集合 $\mathcal{Q}$ の外にロボットが存在でき，光して画像の 明暗も表現するフォーメーション形成問題の検討も望ま れる.

\section{5. おわりに}

本論文では , ロボット群にマスゲームを実現させるた めの分散制御器を開発した . 提案した制御器は, 従来の 被覆制御器とハーフトーン画像処理の考え方を組み合わ せたものであり，光こでの鍵は，与えられた画像の濃淡 情報を, ロボットの密度分布に対応させることであった . また , 产の有効性は, いくつかの異なった性質の標準画 像に対する数值実験を通して明らかにした .

提案法は、「ロボット群にマスゲームを実現させる」と いう目的を掲げたものであるが，さまざまな方向への展 開が考えられる．たとえば, 提案法を別の角度から見る と，前述したハーフトーン画像処理の一手法になってい ることに気付く．このような群ロボットシステムの分散 制御法を利用した手法は,(著者らの知る限り) これまで
にない新しい発想に基づくものである. 谷の方向で新し い可能性が見いだせるかもしれない．また，これまでの 群ロボットシステムの制御では, ノルムで产の性能が測 れるようなものを主な対象としてきたが, 本論文で扱っ たものは, 弚のように簡単には測ることのできない「画 像の見た目」であった．このような, 人間の感性を規範 とする群ロボットシステムの制御への展開も興味深い .

\section{謝辞}

本研究の一部は, 総合科学技術会議により制度設計さ れた最先端研究開発支援プログラム (FIRST 合原最先 端数理モデルプロジェクト) により, 日本学術振興会を 通して助成されたものである .

\section{参考文献}

[1] R. Olfati-Saber, J. A. Fax and R. M. Murray: Consensus and cooperation in networked multi-agent systems; Proceedings of the IEEE, Vol. 95, No. 1, pp. 215-233 (2007)

[2] M. Mesbahi and M. Egerstedt: Graph Theoretic Methods in Multiagent Networks, Princeton University Press (2010)

[3] K. Sugihara and I. Suzuki: Distributed algorithms for formation of geometric patterns with many mobile robots; Journal of Robotic Systems, Vol. 13, No. 3, pp. 127-139 (1996)

[4] I. Suzuki and M. Yamashita: Distributed anonymous mobile robots: Formation of geometric patterns; Society for Industrial and Applied Mathematics Journal of Computation, Vol. 28, No. 4, pp. 1347-1363 (1999)

[5] H. G. Tanner, A. Jadbabaie and G. J. Pappas: Stable Flocking of Mobile Agents, Part I: Fixed Topology; Proceedings of the 42nd IEEE Conference on Decision and Control, pp. 2010-2015 (2003)

[6] J. Cortés, S. Martinez, T. Karatas and F. Bullo: Coverage control for mobile sensing networks; IEEE Transactions on Robotics and Automation, Vol. 20, No. 2, pp. 243-255 (2004)

[7] J. A. Fax and R. M. Murray: Information flow and cooperative control of vehicle formations; IEEE Transactions on Automatic Control, Vol. 49, No. 9, pp. 1465-1476 (2004)

[8] R. Ulichney (Ed.): Digital Halftoning, MIT Press (1987)

[9] 南, 東 , 杉江 : ハーフトーン画像処理: 画像の量子化によ る情報圧縮 ; 計測と制御, Vol. 49, No. 11, pp. 808-813 (2010)

[10] http://www.ess.ic.kanagawa-it.ac.jp/ app_images_j.html 


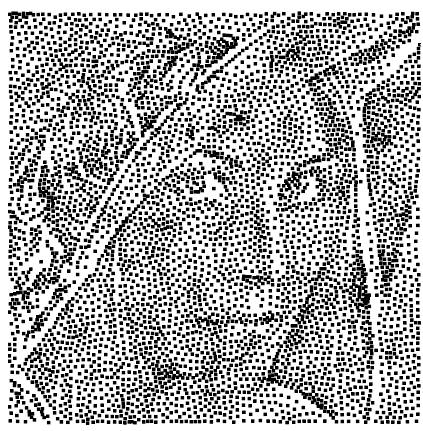

(a) $\phi(q):=e^{10(\varphi(q)-1)}$

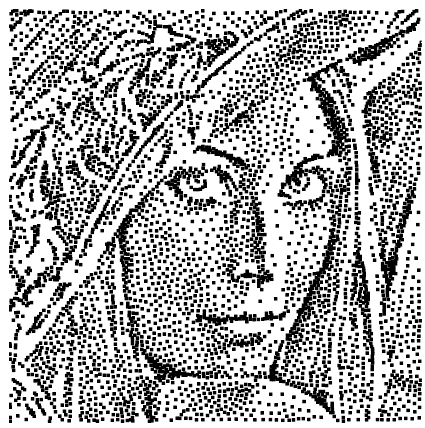

(d) $\phi(q):=e^{40(\varphi(q)-1)}$

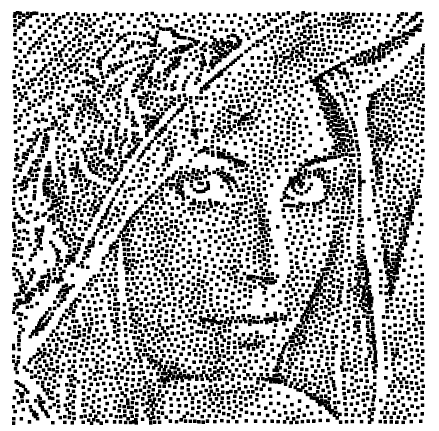

(b) $\phi(q):=e^{20(\varphi(q)-1)}$

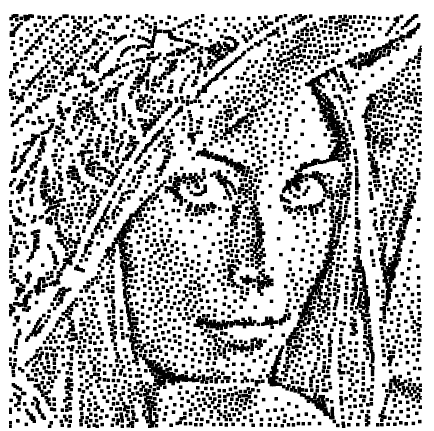

(e) $\phi(q):=e^{50(\varphi(q)-1)}$

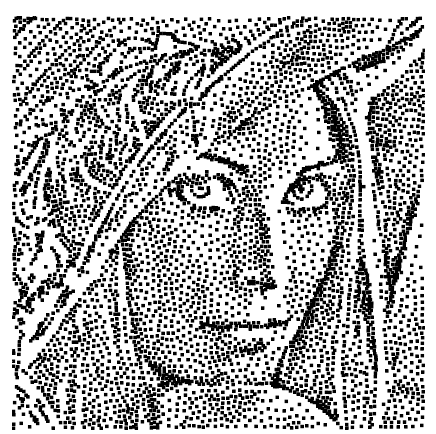

(c) $\phi(q):=e^{30(\varphi(q)-1)}$

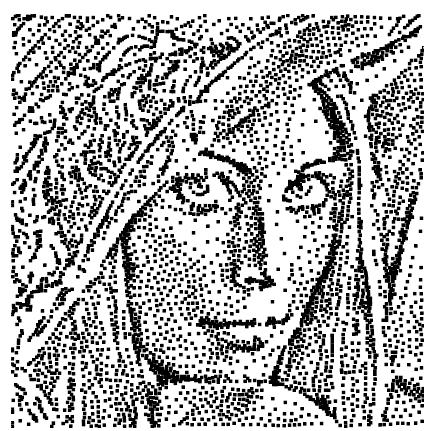

(f) $\phi(q):=e^{60(\varphi(q)-1)}$

Fig. A1 Results of preliminary simulations for selecting $\phi$

付

録

(5) 式を選択するにあたっての予備実験

Fig. A1 は, (5) 式の右辺において, e のべきを変更し た場合の数値実験の結果である.実験にあたっての諸条 件は 4. と同じである . Fig. A1 と Fig. 3 (a)の目標画像 を比較して，今回は， $\phi(q):=e^{30(\varphi(q)-1)}$ を採用した .こ れは , Fig. 3 (a)のモデルの左頬の濃淡はほぼ均一となっ ているが , Fig. A1 (c) がこのことを最もよく表現して いるためである .
著 者 略 歴

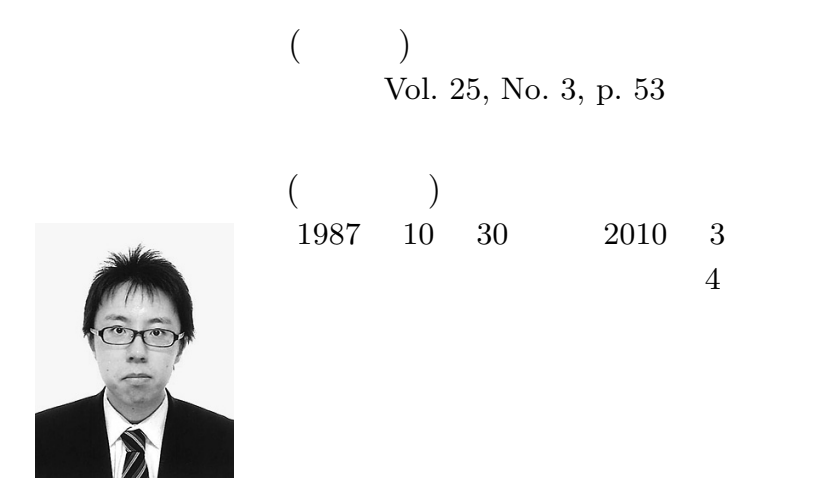

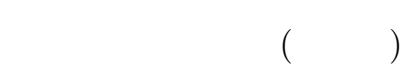

論文誌 Vol. 25, No. 3 , p. 53 参照 